\title{
Evaluasi Tindakan Operatif pada Kanker Serviks, Endometrium dan Ovarium di RSUP Dr. Hasan Sadikin Bandung Tahun 2015-2016
}

\author{
Rosita Indriani, ${ }^{1}$ Mulyanusa A. Ritonga, ${ }^{2}$ Dodi Suardi ${ }^{2}$ \\ ${ }^{1}$ RSUD Waled Kab. Cirebon \\ ${ }^{2}$ Departemen Obstetri dan Ginekologi Fakultas Kedokteran Universitas Padjadjaran \\ Rumah Sakit Dr. Hasan Sadikin Bandung \\ Korespondensi: Rosita Indriani, Email: imel_ros@yahoo.com
}

\begin{abstract}
Abstrak
Tujuan: Mengetahui hasil luaran tindakan operatif pada kanker serviks, endometrium dan ovarium di RSUP Dr. Hasan Sadikin.

Metode: Jenis penelitian dengan mengevaluasi data pasien kanker serviks, endometrium dan ovarium dengan tindakan operatif dari Bagian Rekam Medik RSUP Dr. Hasan Sadikin, Bandung dari Januari 2015-Desember 2016. Variabel yang dievaluasi berupa usia, BMI, paritas, asal kanker, jenis dan komplikasi tindakan operasi.

Hasil: Terdapat 560 kasus yang sesuai dengan kriteria inklusi dari Januari 2015-Desember 2016. Nilai tengah usia pasien 45 tahun, dengan 222 pasien (39,6\%) memiliki BMI normal dan 413 pasien (73,8\%) dengan kanker ovarium. Perdarahan $>2000$ cc terdapat pada 141 kasus $(25,2 \%)$. Durasi operasi terbanyak 3-4 jam pada 208 kasus $(37,1 \%)$. Komplikasi saluran gastrointestinal sebanyak 40 kasus $(7,1 \%)$ dan saluran genitourinaria sebanyak 28 kasus (5\%). Nilai tengah length of stay selama 7 hari, dengan 47 pasien $(8,4 \%)$ memerlukan ICU dan kematian terjadi pada 20 kasus $(3,6 \%)$.

Kesimpulan: komplikasi tersering adalah perdarahan. Tindakan operatif pada kanker serviks lebih berkaitan dengan cedera saluran genitourinaria, sedangkan tindakan operatif pada kanker ovarium lebih berkaitan dengan cedera saluran gastrointestinal.
\end{abstract}

Kata kunci: Kanker ginekologi, operasi dan komplikasi

\section{Evaluation of Operative Procedures on Cervical, Endometrial and Ovarian Cancers in Dr. Hasan Sadikin General Hospital Bandung 2015-2016}

\begin{abstract}
Objectives: To evaluate the post-operative outcomes in patients with cervical, endometrial, and ovarian cancers in Dr. Hasan Sadikin General Hospital in 2015-2016.

Method: We retrospectively evaluated cross-sectionally the charts of these three cancer patients who underwent operative procedures from January 2015 to December 2016 in Dr. Hasan Sadikin Hospital. The following study variables were noted for evaluation: age, BMI, parity, cancer origin, type of surgery, and operative complications. Results: A total of 560 oncologic surgery from these three cancers was undertaken and met the inclusion criteria from January 2015 to December 2016. Median age was 45 years old, with 222 (39,6\%) patients had normal BMI and 413 (73,8\%) patients belonged to ovarian cancer. Operative complications such as bleeding $>2000 c c$ were reported in 141 (25,2\%) cases. The most common length of surgery time was 3-4 hours in 208 (37,1\%) patients. A total of $40(7,1 \%)$ gastrointestinal and $28(5 \%)$ genitourinary tract injuries were encountered. Median length of stay was 7 days, post-operative staying at ICU was noted in 47 (8,4\%) patients and 20 (3,6\%) had intraoperative-related deaths.

Conclusion: The most common complication is bleeding. The operative procedure of cervical cancer is more related to injury to the genitourinary tract, while gastrointestinal tract injury mostly occurs in the operative procedure of ovarian cancer
\end{abstract}

Key words: Gynecological oncology, surgery and complication 


\section{Pendahuluan}

Kanker merupakan salah satu penyebab kematian utama di seluruh dunia. Pada tahun 2012, kanker menjadi penyebab kematian sekitar 8,2 juta orang. Berdasarkan data Global Cancer Incidence, Mortality and Prevalence (GLOBOCAN), International Agency for Research on Cancer (IARC), diketahui bahwa pada tahun 2012 terdapat 14.067.894 kasus baru kanker dan 8.201.575 kematian akibat kanker di seluruh dunia. Di Indonesia, prevalensi kanker adalah sebesar 1,4 per 1.000 penduduk, serta merupakan penyebab kematian nomor $7(5,7 \%)$ dari seluruh penyebab kematian. ${ }^{1}$ Kanker ginekologi adalah kanker yang berasal dari saluran reproduksi wanita, seperti vulva, vagina, serviks, endometrium, ovarium, dan tuba fallopi. ${ }^{2}$ Keganasan ginekologi, seperti kanker serviks, endometrium dan ovarium termasuk dalam jumlah kasus kanker terbanyak pada perempuan di Indonesia. ${ }^{1}$

Penatalaksanaan kanker ginekologi sebagian besar berupa tindakan operatif, baik sebagai pengobatan, staging untuk menentukan tindakan selanjutnya yang akan diambil, maupun keduanya. Sebagian besar dari kanker ginekologi, seperti kanker ovarium, endometrium dan vulva diterapi dan di staging secara operatif., ${ }^{4}$ Tindakan operatif berguna sebagai staging maupun sitoreduksi (debulking). ${ }^{5-7}$ Setiap prosedur operatif memiliki risiko untuk terjadinya komplikasi. ${ }^{8}$ Komplikasi operasi adalah hasil yang tidak diinginkan dan tidak disengaja dari suatu operasi yang mempengaruhi pasien sebagai hasil langsung dari tindakan operatif tersebut. ${ }^{9,10}$ Pada tindakan operatif, beberapa kesalahan dapat dihindari sepenuhnya dan sebagian tidak dapat dihindari. Kesalahan yang tidak dapat dihindari lebih sering terjadi pada operasi keganasan dalam panggul karena anatomi organ panggul yang terdistorsi oleh kanker maupun terjadinya metastasis pada organ tersebut. ${ }^{3,11}$
Insidensi komplikasi tindakan operatif pada kasus ginekologi onkologi lebih tinggi dibandingkan kasus ginekologi umum bila dilihat dari kompleksitas operasi. ${ }^{12}$ Tindakan operatif pada seluruh keganasan ginekologi tidak saja mencakup reseksi dari tumor primer, tetapi juga evaluasi dari penyebaran lokal maupun jauh dari sel tumor. Beberapa komplikasi pada operasi ginekologi berhubungan dengan perjalanan penyakit, prosedur tindakan dan karakteristik pasien. ${ }^{3}$ Data mengenai mortalitas dan morbiditas setelah operasi ginekologi seringkali tidak dilaporkan. Oleh karena itu, pegumpulan data yang andal dan valid mengenai prosedur ginekologi dari tinjauan status dengan memeriksa komorbiditas medis praoperasi akan memberikan pemahaman tentang komplikasi pasca operasi dari prosedur ini. ${ }^{8}$ Dengan adanya penjelasan dan hal-hal tersebut di atas maka penulis berkeinginan untuk melakukan penelitian dalam masalah tersebut.

\section{Metode}

Penelitian ini merupakan hospital based study yang bersifat deskriptif, dengan data berasal dari rekam medik pasien di RSUP Dr. Hasan Sadikin periode Januari 2015-Desember 2015.

Subjek penelitian ini adalah pasien kanker endometrium, ovarium dan serviks yang pernah dirawat dan dilakukan tindakan operatif di bagian Obstetri Ginekologi RSUP Dr. Hasan Sadikin, Bandung periode 1 Januari 2015-31 Desember 2016. Kriteria inklusi pada penelitian ini yaitu semua kelompok usia, telah dilakukan prosedur pemeriksaan sampai dengan penegakan diagnosis kanker endometrium, ovarium dan serviks, dan telah dilakukan tindakan operatif sebagai terapi. Pasien dengan hasil pemeriksaan patologi anatomi yang inkonklusif dan pasien yang tidak dilakukan tindakan operatif tidak termasuk dalam penelitian ini. Penelitian ini 
dimulai dengan mengidentifikasi data rekam medis, kemudian dilakukan penelusuran faktor demografi dan klinis berdasarkan diagnosis operasional. Apabila ditemukan variabel yang tidak lengkap, maka pasien tersebut tereksklusi. Data dikumpulkan, diolah dan hasilnya disajikan secara deskriptif. Perhitungan deskriptif dilakukan berdasarkan jumlah dan persentase.

\section{Hasil}

Selama periode tersebut didapatkan 576 kasus dengan tindakan operatif pada kanker serviks, endometrium dan ovarium, 560 kasus diantaranya memenuhi kriteria inklusi. Karakteristik subyek penelitian dapat dilihat pada tabel 1 .

Tabel 1 memperlihatkan keganasan ginekologi yang tersering berasal dari ovarium, sebanyak 413 kasus $(73,8 \%)$, diikuti 87 kasus $(15,5 \%)$ berasal dari serviks dan 60 kasus $(10,7 \%)$ berasal dari endometrium. Secara keseluruhan karakteristik subyek penelitian berdasarkan umur memiliki rentang 4-81 tahun dan nilai tengah 45 tahun.

Nilai tengah umur termuda didapatkan pada kanker serviks (42 tahun), sedangkan rentang umur terlebar didapatkan pada kanker ovarium (4-81 tahun). Mayoritas pasien memiliki Body Mass Index (BMI) normal, sebanyak 222 pasien $(39,6 \%)$ diikuti dengan kelompok over-weight, yaitu sebanyak 180 pasien $(32,1 \%)$. Paritas terbanyak terdapat pada kelompok multipara, yaitu 204 kasus (36,4\%). Pada kanker endometrium dan ovarium, kelompok paritas terbanyak pada nullipara yaitu $41,7 \%$ dan $37 \%$, sedangkan pada kanker serviks kelompok terbanyak pada multipara $(68,8 \%)$.

Untuk kanker ovarium, 63\% (260 dari 413) operasi adalah complete surgical staging, diikuti dengan debulking 20,1\% (83 dari 413) dan 16,9\% (70 dari 413) conservative surgical staging.

Pada kanker serviks, prosedur yang tersering dilakukan adalah histerektomi radikal disertai limfadenektomi pelvik bilateral yaitu sebanyak $69 \% \quad(60$ dari 87). Tindakan Laterally Extended Parametrectomy (LEP) dilakukan pada 21,9\% (19 dari 87), sedangkan tindakan operatif per laparoskopi hanya dilakukan pada 2,3\% (2 dari 87 kasus). Mayoritas kanker endometrium dilakukan tindakan operatif histerektomi totalis, 36,7\% (22 dari 60) secara terbuka dan 33,3\% (20 dari 60) per laparoskopik. Pada 16,7\% (10 dari 60)

Tabel 1 Karakteristik Subjek Penelitian

\begin{tabular}{lcccc}
\hline \multicolumn{1}{c}{ Variabel } & Total & $\begin{array}{c}\text { Kanker } \\
\text { Serviks }\end{array}$ & $\begin{array}{c}\text { Kanker } \\
\text { Endometrium }\end{array}$ & $\begin{array}{c}\text { Kanker } \\
\text { Ovarium }\end{array}$ \\
\cline { 3 - 4 } & $\mathbf{n = 5 6 0}$ & $\mathbf{n = 8 7}$ & $\mathbf{n = 6 0}$ & $\mathbf{n = 4 1 3}$ \\
& & & & \\
\hline Median umur (rentang) & $45(4-81)$ & $42(20-68)$ & $55(30-74)$ & $45(4-81)$ \\
BMI & & & & \\
Under-weight $(<18.5)$ & $124(22,1 \%)$ & $20(23 \%)$ & - & $104(25,2 \%)$ \\
Normal $(18.5-24.9)$ & $222(39,6 \%)$ & $37(42,5 \%)$ & $5(8,3 \%)$ & $180(43,6 \%)$ \\
Over-weight $(25-29.9)$ & $180(32,1 \%)$ & $27(31 \%)$ & $36(60 \%)$ & $87(21,1 \%)$ \\
Obese $(30-39.9)$ & $20(3,6 \%)$ & $3(3,55 \%)$ & $13(21,7 \%)$ & $34(8,2 \%)$ \\
Morbid obese $(\geq 40)$ & $14(2,5 \%)$ & - & $6(10 \%)$ & $8(1,9 \%)$ \\
Paritas & & & & \\
$\quad$ Nullipara $(0)$ & $183(32,7 \%)$ & $5(6,3 \%)$ & $25(41,7 \%)$ & $153(37 \%)$ \\
Primipara $(<2)$ & $173(30,9 \%)$ & $27(33,8 \%)$ & $18(30 \%)$ & $128(31 \%)$ \\
Multipara $(\geq 2)$ & $204(36,4 \%)$ & $55(68,8 \%)$ & $17(28,3 \%)$ & $132(32 \%)$ \\
\hline
\end{tabular}


Tabel 2 Jenis Tindakan Operatif

\begin{tabular}{lccc}
\hline \multicolumn{1}{c}{ Prosedur } & $\begin{array}{c}\text { Kanker } \\
\text { Serviks }\end{array}$ & $\begin{array}{c}\text { Kanker Endo- Kanker Ovarium } \\
\text { metrium }\end{array}$ & \\
\cline { 2 - 4 } & $\mathbf{n ~ ( \% )}$ & $\mathbf{n ~ ( \% )}$ & $\mathbf{n ~ ( \% )}$ \\
\hline Histerektomi radikal \pm SOB \pm limfadenektomi & $60(69 \%)$ & $10(16,7 \%)$ & \\
Laterally extended parametrectomy (LEP) & $19(21,9 \%)$ & & \\
Trakelektomi & $4(4,6 \%)$ & & $260(63 \%)$ \\
Complete surgical staging & & & $83(20,1 \%)$ \\
Debulking & $2(2,3 \%)$ & $8(13,3 \%)$ & $70(16,9 \%)$ \\
Conservative Surgery & & & \\
Histerektomi totalis \pm SOB/SOU & & $22(36,7 \%)$ & \\
Total Laparoscopic Hysterectomy & $2(2,3 \%)$ & $20(33,3 \%)$ & \\
\hline
\end{tabular}

Tabel 3 Komplikasi Tindakan Operatif

\begin{tabular}{|c|c|c|c|c|}
\hline Variabel & Total & $\begin{array}{c}\text { Kanker } \\
\text { Ovarium }\end{array}$ & $\begin{array}{c}\text { Kanker } \\
\text { Endometrium }\end{array}$ & $\begin{array}{l}\text { Kanker } \\
\text { Serviks } \\
\end{array}$ \\
\hline & $n=560$ & $n=413$ & $n=60$ & $\mathrm{n}=\mathbf{8 7}$ \\
\hline Gastro Intestinal & $40(7,1)$ & $35(8,5)$ & $3(5)$ & $2(2,3)$ \\
\hline Genito Urinaria & $28(5)$ & $18(4,4)$ & $2(3,3)$ & $8(9,2)$ \\
\hline $\begin{array}{l}\text { Perdarahan } \\
<1000 \mathrm{cc} \\
1000-2000 \mathrm{cc} \\
>2000 \mathrm{cc}\end{array}$ & $\begin{array}{l}205(36,6) \\
214(38,2) \\
141(25,2)\end{array}$ & $\begin{array}{c}110(26,6) \\
196(47,5) \\
107(25,9) \\
4(0-12)\end{array}$ & $\begin{array}{c}34(56,7) \\
14(23,3) \\
12(20) \\
2(0-6)\end{array}$ & $\begin{array}{c}61(70,1) \\
4(4,6) \\
22(25,3) \\
4(0-14)\end{array}$ \\
\hline $\begin{array}{l}\text { Median Jumlah } \\
\text { Transfusi PRC } \\
\text { (rentang) }\end{array}$ & $2(0-14)$ & & & \\
\hline Lama Operasi & & $24(5,8)$ & $6(10)$ & - \\
\hline$-<1$ jam & $30(5,4)$ & $13(3,1)$ & $29(48,3)$ & $4(4,6)$ \\
\hline$-1-2$ jam & $46(8,2)$ & $164(39,7)$ & $10(16,7)$ & $2(2,3)$ \\
\hline$-2-3$ jam & $176(31,3)$ & $166(40,2)$ & $5(8,3)$ & $37(42,5)$ \\
\hline$-3-4$ jam & $208(37,1)$ & $46(11,1)$ & $10(16,7)$ & $44(50,6)$ \\
\hline$->4$ jam & $100(17,9)$ & $38(9,2)$ & & $9(10,3)$ \\
\hline Rawat ICU & $47(8,4)$ & $16(3,9)$ & - & \\
\hline Kematian & $20(3,6)$ & $7(4-40)$ & $5(4-10)$ & $9(4-20)$ \\
\hline $\begin{array}{l}\text { Median Lama } \\
\text { (perawatan rentang) }\end{array}$ & $7(4-40)$ & & & \\
\hline Wound dehiscence & $32(5,7)$ & $25(6,1)$ & $2(3,3)$ & $5(5,8)$ \\
\hline
\end{tabular}

Sebanyak 40 pasien $(7,1 \%)$ mengalami komplikasi pada saluran gastrointestinal dan 28 pasien $(5 \%)$ mengalami komplikasi pada saluran genitourinaria. Komplikasi pada saluran gastrointestinal dan genitourinaria terbanyak didapatkan pada tindakan operatif pada kanker ovarium, yaitu sebanyak 35

kasus $(8,5 \%)$ dan 18 kasus (4,4\%).Jumlah perdarahan tersering yaitu pada kelompok 1000-2000 cc sebanyak kasus 214 (38,2\%), diikuti dengan perdarahan sebanyak $<1000 \mathrm{cc}$ pada 205 kasus $(36,6 \%)$. Tindakan operatif pada keganasan yang berasal dari ovarium merupakan tindakan dengan risiko 
dilakukan histerektomi radikal, sedangkan 13,3\% (8 dari 60) dengan stadium lanjut hanya dilakukan debulking. perdarahan terbesar yaitu sebanyak 1000-2000 cc pada 196 kasus (47,5\%). Nilai tengah jumlah transfusi yang digunakan untuk mengatasi perdarahan yaitu sebanyak 2 labu PRC (0-14).

Durasi operasi terbanyak terjadi pada kelompok 3-4 jam sebanyak 208 kasus (37,1\%) diikuti kelompok 2-3 jam sebanyak 176 kasus $(31,4 \%)$. Tindakan operatif pada kanker endometrium merupakan tindakan dengan mayoritas durasi tersingkat, yaitu 1-2 jam pada 29 kasus (48,3\%).

Perawatan intensif pasca operasi dibutuhkan pada 47 kasus $(8,4 \%)$. Sebagian besar pada keganasan yang berasal dari ovarium, yaitu sebanyak 38 kasus $(9,2 \%)$. Kematian terjadi pada 20 kasus $(3,6 \%), 16$ kasus $(3,9 \%)$ berasal dari kanker ovarium dan 4 kasus $(4,6 \%)$ berasal dari kanker serviks. Tidak terdapat kematian maupun kasus yang membutuhkan perawatan intensif pada kanker endometrium.

Nilai tengah perawatan pasien secara keseluruhan yaitu 7 hari dengan rentang 4-40 hari. Nilai tengah lama perawatan terlama yaitu pada kanker serviks ( 9 hari). Rentang lama perawatan terjauh terjadi pada kanker ovarium yaitu 4-40 hari. Sedangkan nilai tengah dan rentang lama perawatan terkecil didapatkan pada kanker endometrium yaitu 5 hari (4-10).

Secara keseluruhan, terdapat 32 kasus $(5,7 \%)$ wound dehiscence. Dua puluh lima kasus berasal dari kanker ovarium dan 5 kasus dari kanker serviks. Hanya terdapat 2 kasus wound dehiscence pada kanker endometrium.

\section{Pembahasan}

Komplikasi operasi adalah sesuatu yang tidak diinginkan dari suatu operasi yang mempengaruhi pasien sebagai hasil langsung dari tindakan operatif tersebut. ${ }^{9,10}$ Keganasan merupakan faktor risiko independen untuk terjadinya cedera iatrogenik intraoperatif. ${ }^{11}$ Pada penelitian ini dilakukan evaluasi terhadap beberapa faktor yang menjadi komplikasi pada tindakan operatif keganasan yang berasal dari serviks, ovarium, serta endometrium.

Dalam penatalaksanaan kanker ginekologi, pengetahuan yang luas tentang anatomi panggul sangat penting karena penyakit ini dapat secara signifikan menghambat pandangan dan aksesibilitas bagi operator sehingga berpotensi berkontribusi terhadap cedera iatrogenik pada genitourinaria maupun gastrointestinal. ${ }^{12}$ Risiko terjadinya cedera pada saluran genitourinaria pada operasi ginekologi disebabkan karena letaknya yang berdekatan dengan pembuluh darah yang memperdarahi uterus dan ovarium. Faktor risiko terjadinya cedera yaitu perlengketan pada organ panggul, keganasan dan riwayat radiasi sebelumnya. ${ }^{13}$

Pada penelitian ini, didapatkan adanya komplikasi yang terjadi pada saluran genitourinaria $(5 \%)$ dan gastrointestinal $(7,1 \%)$ seperti yang dilaporkan oleh Rettenmaier dkk, meskipun penelitian mereka membandingkan antara prosedur operasi secara laparotomi dan laparoskopik. ${ }^{12}$ Pada operasi keganasan rongga pelvis, sering ditemukan cedera iatrogenik pada saluran genitourinaria. Cedera ureter merupakan yang tersering, diikuti oleh cedera kandung kemih dan yang lebih jarang yaitu cedera urethra. ${ }^{11}$ Prevalensi keseluruhan semua komplikasi pasca operasi (termasuk infeksi saluran kemih) pada studi yang mereka lakukan yaitu sebesar $9,0 \% .{ }^{8}$ Suatu studi besar terhadap 2616 pasien yang menjalani operasi kanker rahim menemukan bahwa sekitar $1 \%$ pasien mengalami cedera kandung kemih sedangkan penelitian lain menemukan bahwa sekitar 1\% pasien mengalami cedera ureter. $^{3}$

Cedera saluran cerna biasanya terjadi saat dilakukan adhesiolisis atau saat sedang dilakukan diseksi pada posterior cul-de-sac, maupun karena invasi dari tumor. ${ }^{11}{ }^{13}$ Pada 
penelitian ini didapatkan mayoritas cedera saluran cerna terjadi pada kanker ovarium, yaitu sebanyak 7,8\% (32 dari 413). Hal ini mungkin disebabkan karena lebih dari $70 \%$ pasien kanker ovarium dengan stadium III $\mathrm{C}$ atau seterusnya pada saat terdiagnosis terdapat metastasis ke perut bagian atas dengan keterlibatan kelenjar getah bening, usus, atau keduanya. Akibat keadaan tersebut, optimal debulking keganasan ovarium sering melibatkan manipulasi atau reseksi usus kecil dan besar. Hal ini dapat menyebabkan cedera usus intraoperatif atau komplikasi post operatif, seperti ileus usus, obstruksi, kebocoran anastomosis atau pembentukan fistula. Komplikasi ini meningkat dengan peningkatan kompleksitas bedah, seperti tindakan eksenterasi, sitoreduksi kanker ovarium yang radikal. $^{3}$ Perdarahan intraoperatif didefinisikan sebagai perdarahan $>1000 \mathrm{~mL}$ atau kehilangan darah selama operasi yang membutuhkan transfusi darah. Perdarahan intraoperatif telah dilaporkan pada $1 \%$ sampai $2 \%$ dari tindakan histerektomi. ${ }^{14}$ Pada penelitian ini perdarahan intra operatif $<1000 \mathrm{cc}$ hanya terjadi pada $36,6 \%$, selebihnya perdarahan terjadi $>1000 \mathrm{cc}$. Hal ini menunjukkan bahwa perdarahan pada kasus-kasus keganasan seringkali tidak dapat dihindari. Penderita kanker berisiko mengalami pendarahan intra maupun post operatif yang signifikan karena faktor terkait tumor seperti invasi struktur vaskular maupun hipervaskularisasi jaringan kanker itu sendiri. Perdarahan dapat terjadi secara tak terduga dan tak terkendali selama periode perioperatif sehingga dapat meningkatkan angka kematian. ${ }^{15}$

Kemungkinan penderita kanker untuk mendapatkan transfusi lebih besar bila dibandingkan dengan pasien non-kanker. ${ }^{15}$ Perdarahan intra atau pasca operasi menyebabkan transfusi setelah operasi untuk kanker ginekologis pada $<1$ sampai $>30 \%$ pasien, tergantung pada modalitas bedah, radikalitas dan keadaan umum pasien. ${ }^{3}$
Seperti halnya yang terjadi pada pasienpasien yang menjadi subyek penelitian ini. Mayoritas perdarahan $>1000$ cc yang terjadi selama operasi menyebabkan pasien-pasien tersebut membutuhkan transfusi baik intra maupun post operatif. Dari keseluruhan, nilai tengah jumlah transfusi yang dibutuhkan adalah 2 labu Packed Red Cell (PRC).

Berdasarkan studi yang dilakukan oleh Stepp dkk, durasi operasi merupakan salah satu faktor yang mempengaruhi komplikasi post operatif. Faktor lain yang mempengaruhi yaitu penyakit vascular dan penyakit koroner. ${ }^{8}$ Pada penelitian ini, mayoritas waktu yang dibutuhkan untuk tindakan operatif yaitu 3-4 jam (37, 1\%). Durasi yang dibutuhkan untuk setiap tindakan operatif tergatung dari kompleksitas prosedur, seperti tindakan operatif kanker ovarium, kanker serviks, maupun kanker endometrium dengan penyebaran ke serviks. Pada kanker ovarium standar dari surgical staging berupa bilasan peritoneum, histerektomitotalis, dan salpingoooforektomi bilateral, inspeksi dari seluruh organ abdomen dan permukaan peritoneum, biopsi dari area yang mencurigakan, omentektomi totalis, dan limfadenektomi kelenjar para aortik. ${ }^{4,5}$ Sedangkan pada kanker serviks, apabila tumor telah menyebar diluar serviks maka tujuan tindakan operatif yaitu untuk mereseksi seluruh jaringan ikat pada pelvis. Kompleksitas pada prosedurprosedur tersebut menyebabkan waktu yang dibutuhkan menjadi lebih panjang dibandingkan dengan operasi ginekologi biasa.

Risiko infeksi pascaoperasi seperti infeksiluka operasi, ditemukan pada $3 \%-10 \%$ Beberapa cara telah direkomendasikan oleh Centers for Disease Control and Prevention untuk menurunkan risiko terjadinya infeksi, seperti membersihkan diri dengan sabun antiseptik sebelum operasi dan penggunaan povidone iodine maupun chlorhexidine pada kulit. Penggunaan antibiotik intravena sebagai profilaksis 1 jam sebelum prosedur 
telah terbukti meurunkan infeksi post operatif $25 \%-30 \%$. Antibiotik dengan spektrum luas menjadi pilihan untuk profilaksis. Cefazolin (1g) merupakan antibiotik yang paling sering digunakan karena waktu paruh yang relatif panjang dan harga yang terjangkau. ${ }^{13}$ Obesitas merupakan faktor risiko independen pada infeksi luka post operatif. ${ }^{13}$

Pada penelitian ini didapatkan hanya 32 kasus $(5,7 \%)$ wound dehiscence. Hal ini mungkin disebabkan karena pada semua pasien yang akan dilakukan tindakan operatif, sebelumnya telah dilakukan tindakan-tindakan pencegahan yang sudah direkomendasikan. Selain itu, mayoritas pasien yang menjadi subyek dalam penelitian ini memiliki BMI normal $(39,6 \%)$

Pada penelitian ini dapat dilihat adanya peningkatan komplikasi post operatif pada kanker ovarium dan serviks yang mungkin disebabkan tindakan operatif yang kompleks (surgical staging, histerektomi radikal, maupun LEP). Meningkatnya komplikasi post operatif dapat dilihat dari meningkatnya jumlah perdarahan, durasi operasi yang lebih panjang, serta kebutuhan akan perawatan intensif pasca operasi Simpulan, terdapat 560 kasus keganasan dengan tindakan operatif yang berasal dari serviks, endometrium dan ovarium selama periode 2015-2016. Sebagian besar kasus keganasan berasal dari ovarium, diikuti oleh serviks dan endometrium.

Komplikasi yang tersering adalah perdarahan. Komplikasi lainnya terkadang sulit dihindari karena anatomi organ panggul yang terdistorsi oleh massa tumor, serta adanya metastasis pada organ.Sulitnya tindakan operatif juga mempengaruhi lamanya waktu operasi. Cedera pada saluran genitourinaria dan gastro intestinal terkadang tidak dapat dihindari. Tindakan operatif pada kanker serviks lebih berkaitan dengan cedera pada saluran genitourinaria, sedangkan cedera saluran gastro intestinal sebagian besar terjadi pada tindakan operatif kanker ovarium.

\section{Saran}

Persiapan dan perencanaan sebelum tindakan operatif untuk meminimalkan komplikasi pada tindakan operatif. Pengetahuan operator yang luas tentang anatomi panggul sangat penting agar dapat menghindari cedera iatrogenik. Dengan mengetahui komplikasi intra operatif dan post operatif dapat menurunkan risiko morbiditas pada pasien. Mengenali cedera sebelum dilakukan penutupan, sehingga dapat dilakukan tatalaksana sesegera mungkin dan menghindari komplikasi pasca operasi serta kemungkinan untuk dilakukannya operasi kedua.

\section{Daftar Pustaka}

1. Informasi Situasi Penyakit Kanker. Buletin Jendela dan Informasi Kesehatan. Edisi ke 1. Jakarta: Kementerian Kesehatan RI; 2015. h. 1-11.

2. The Inside Knowledge: Get the Facts About Gynecologic Cancer. In: Prevention CDC, editor. Atlanta: CDC Publication; 2012.

3. Horvath S, George E, Herzog TJ. Unintended Consequences: Surgical complications in gynecologic cancer. Women's health 2013;9(6):595-604.

4. Doubeni $\mathrm{CH}$, Myers AE. Diagnosis and Management of Ovarian Cancer. Am Fam Physician. 2016;93(11):937-44.

5. Camean MM, Sánchez ED, Pinera A, Diestro MD, De Santiago J, Zapardiel I. The Role of Surgery in Advanced epithelial ovarian cancer. ecancer 2016;10(666).

6. Lachance JA Darus CJ, Rice LW. Surgical management and postoperative treatment of endometrial carcinoma. Revised obstetrics and gynecology. 2008;1(3):97105.

7. Halkia E Kalinoglou N, Spiliotis J. Surgical management of endometrial 
cancer: a critical review. J BUON 2012;17:637-64.

8. Erekson EA, Yip SO, Ciarleglio MM, Terri R., Fried M. Postoperative complications after gynecologic surgery. Obstetrics and Gynecology. 2011;118(4):785-93.

9. Iyer R, Nordin A, Burnell M, Liston R, Manchanda R, Das N, et al. Predictors of complications in gynaecological oncological surgery: a prospective multicentre study (UKGOSOC-UK gynaecological oncology surgical outcomes and complications). $\mathrm{Br} \mathrm{J}$ Cancer. 2015;112:475-84.

10. Iyer R. Surgical Outcomes in Gynaecological Oncology. London: University College London; 2015.

11. Neagoe CO, Mazilu O. Pelvic intraoperative iatrogenic oncosurgical injuries: single center experience $\mathrm{J}$ BUON 2016;21(2):498-504.
12. Rettenmaier CR, Rattenmaier N, Abaid LN, Brown JV, Micha JP, Mendivil AA, Wojciechowski T, Goldstein BH, Markman M. The incidence of genitourinary and gastrointestinal complications in open and endoscopic gynecologic cancer surgery. Oncology. 2014;86:303-7.

13. Stany $\mathrm{mp}$, farley $\mathrm{jh}$. Complications of gynecologic surgery. Surg clin $\mathrm{n}$ am. 2008;88:343-59.

14. $\mathrm{Yu}$ SP Cohen JG, Parker WH. Management of hemorrhage during gynecologic surgery. Clin Obstet Gynecol. 2015;58(4):718-73.

15. Cata JP, Gottumukkala V. Blood loss and massive transfusion in patients undergoing major oncological surgery: what do we know? ISRN Anesthesiol. 2012:1-11. 